\title{
On the Fly: Tritrophic Associations of Bats, Bat Flies, and Fungi
}

\author{
Michiel D. de Groot ${ }^{1, *(\mathbb{D}}$, Iris Dumolein ${ }^{2}\left(\mathbb{D}\right.$, Thomas Hiller ${ }^{3,4,5}{ }^{(}$, Attila D. Sándor ${ }^{6,7} \mathbb{D}^{\circ}$, \\ Tamara Szentiványi $\left.{ }^{8}{ }^{(}\right)$, Menno Schilthuizen ${ }^{1}\left(\mathbb{D}\right.$, M. Catherine Aime ${ }^{9}\left(\mathbb{D}\right.$, Annemieke Verbeken ${ }^{2}$ \\ and Danny Haelewaters $2,5,9$ (1)
}

1 Research Group Evolutionary Ecology, Naturalis Biodiversity Center, Darwinweg 2, 2333CR Leiden, The Netherlands; menno.schilthuizen@naturalis.nl

2 Research Group Mycology, Department of Biology, Ghent University, K.L. Ledeganckstraat 35, 9000 Ghent, Belgium; iris.dumolein@ugent.be (I.D.); mieke.verbeken@ugent.be (A.V.); danny.haelewaters@gmail.com (D.H.)

3 Ecology of Tropical Agricultural Systems, University of Hohenheim, Garbenstrasse 13, 70599 Stuttgart, Germany; thomas.hiller@uni-hohenheim.de

4 Institute of Evolutionary Ecology and Conservation Genomics, University of Ulm, Albert-Einstein-Allee 11, 89081 Ulm, Germany

5 Smithsonian Tropical Research Institute, Apartado 0843-03092, Balboa, Panama

6 Department of Parasitology and Parasitic Diseases, University of Agricultural Sciences and Veterinary Medicine, Calea Mănăștur 3-5, 400372 Cluj-Napoca, Romania; adsandor@gmail.com

7 Department of Parasitology and Zoology, University of Veterinary Medicine, István u. 2, 1078 Budapest, Hungary

8 Pathogen and Microbiome Institute, Northern Arizona University, 1395 S. Knoles Drive, Flagstaff, AZ 86011, USA; tamaraszentivanyi@gmail.com

9 Department of Botany and Plant Pathology, Purdue University, 915 W. State Street, West Lafayette, IN 47906, USA; maime@purdue.edu

* Correspondence: michielddegroot@gmail.com

Academic Editor: Gudrun Wibbelt

Received: 23 November 2020; Accepted: 11 December 2020; Published: 12 December 2020

\begin{abstract}
Parasitism is one of the most diverse and abundant modes of life, and of great ecological and evolutionary importance. Notwithstanding, large groups of parasites remain relatively understudied. One particularly unique form of parasitism is hyperparasitism, where a parasite is parasitized itself. Bats (Chiroptera) may be parasitized by bat flies (Diptera: Hippoboscoidea), obligate blood-sucking parasites, which in turn may be parasitized by hyperparasitic fungi, Laboulbeniales (Ascomycota: Laboulbeniomycetes). In this study, we present the global tritrophic associations among species within these groups and analyze their host specificity patterns. Bats, bat flies, and Laboulbeniales fungi are shown to form complex networks, and sixteen new associations are revealed. Bat flies are highly host-specific compared to Laboulbeniales. We discuss possible future avenues of study with regard to the dispersal of the fungi, abiotic factors influencing the parasite prevalence, and ecomorphology of the bat fly parasites.
\end{abstract}

Keywords: bat flies; Chiroptera; food webs; host specificity; hyperparasites; Laboulbeniales; parasites

\section{Introduction}

The world today is undergoing fast anthropogenic changes. Five major changes pose a direct threat to biodiversity and ecosystem functioning: climate change, habitat alteration, exploitation, pollution, and invasive species [1]. While scientists try to halt biodiversity loss through conservation strategies, they often seem to neglect considering parasites [2,3]. Parasitism is one of the most diverse 
modes of life [4,5]. Parasites are thought to have evolved as often as, if not more often than, other types of organisms [6,7]. Parasites are important drivers of adaptive change [8]. They are known to alter food webs either indirectly through enhancing their transmission rate by altering life-history traits of their hosts, or directly by changing the food chain length, number of links, and energy flows, with possibly as many as $75 \%$ of links in food webs involving a parasitic species $[9,10]$. Finally, parasites play important roles as bioregulators of population dynamics.

Whereas they are prevalent and vital for their ecosystem, parasites are vastly understudied and the effects of parasites on their hosts and vice versa are often still unclear [3,11]. Parasites face the same and perhaps even larger threats compared to other organisms due to their dependence on other species for their survival [5]. Obligate parasites, those that cannot survive without a suitable host, are often co-endangered once the ecosystem and natural relations are out of balance; when a host faces endangerment or extinction, as a consequence, its parasite(s) will too. Ultimately, when the host goes extinct, this will lead to co-extinction of its parasite(s), resulting in a cascade reaction of secondary extinctions [12]. As a result, the loss of parasite biodiversity contributes a significant amount to the current sixth mass extinction [5]. This calls for a need to include parasites in integrative conservation strategies.

An important determinant of loss of parasite biodiversity is host specificity. It is known that in some cases, when parasites are less host-specific, they can save themselves from co-extinction by shifting to alternative hosts $[13,14]$. Host specificity of parasites is a key factor determining their geographical range [15,16], their ability to colonize and survive on a new host [17], and the likelihood of host-parasite co-extinction risk [18]. Host specificity can be measured at different levels: (i) structural specificity, the distribution of parasite populations across hosts and the relative frequency specific parasites exploit specific hosts, (ii) phylogenetic specificity, a measure of phylogenetic relatedness among hosts that a parasite prefers or the phylogenetic relatedness of parasites that prefer a specific host, and (iii) geographical specificity, a measure of how parasites distribute themselves across hosts on different spatial scales [19].

One particular type of parasitism is hyperparasitism (Figure 1). Hyperparasitism is an interaction where a parasite itself is infected with another parasite [20]. Although it might appear "a risky lifestyle" at first glance, hyperparasitism is thought to be a common phenomenon in nature [20-22]. Hyperparasites can play a role in altering the population sizes of their hosts. Since these hosts are parasites themselves, the hyperparasites may indirectly affect the primary host population sizes, too [23]. As such, tritrophic interactions can alter the patterns of energy flow in food webs and have an impact on the overall biodiversity as well as population dynamics. One example of obligate hyperparasitism, where one parasite is parasitized by a secondary parasite that on its own cannot parasitize an uninfected primary host [24], is presented by the associations found among bats (Mammalia: Chiroptera), bat flies (Diptera: Hippoboscoidea), and Laboulbeniales fungi (Ascomycota: Laboulbeniomycetes).

Bats are nocturnal animals with a long life-span, slow reproduction rates, a high metabolism, improved mobility, and variable in sociality-living either solitary or in large colonies. The clade is the second-largest order within Mammalia, with about 1426 described species [25]. They inhabit different roosting structures from ephemeral leaf tents to caves and mines [26]. Bats are keystone species with many ecosystem functions, such as seed dispersal, pollination, insect population control, and suppression of pest-associated fungal growth and mycotoxin in corn $[27,28]$. Sixteen percent of bat species are listed in threatened categories: critically endangered (CE), endangered (EN), and vulnerable (VU), whereas seven percent are near threatened (NT) [29]. These numbers indicate that bat populations around the world are facing serious threats [30]. The ecology and biology of bats contribute to the fact that they are parasitized by different lineages of organisms, including bugs (Hemiptera), earwigs (Dermaptera) (but see [31]), mites and ticks (Acari), fleas (Siphonaptera), and, most conspicuously, the bat flies (Diptera) [32,33]. 


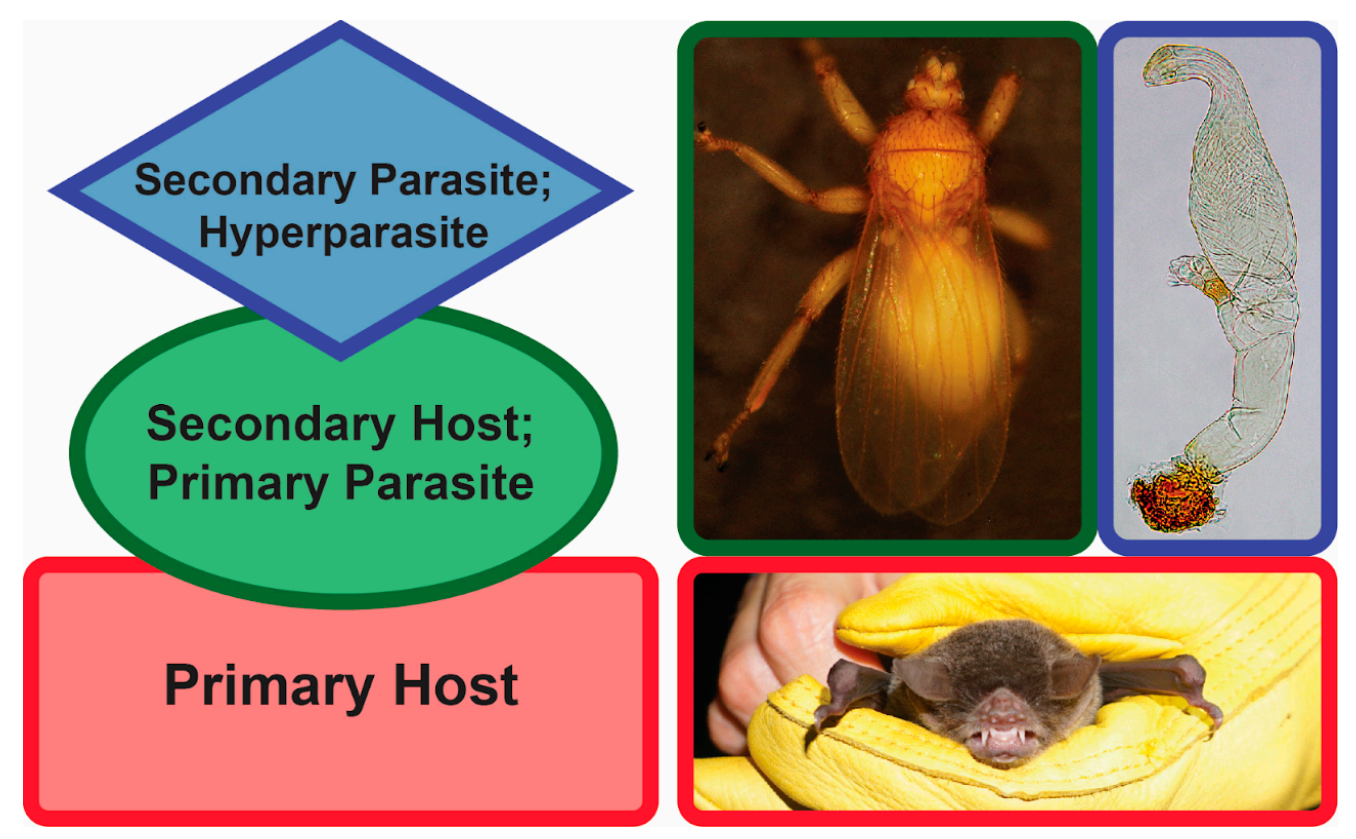

Figure 1. Hyperparasitism. Left, generalized diagram of hyperparasitism. Red, primary host (bat); green, secondary host/primary parasite (bat fly); blue, secondary parasite/hyperparasite (fungus). Right, Pteronotus parnellii (Mormoopidae), Trichobius yunkeri (Streblidae), Gloeandromyces nycteribiidarum (Laboulbeniales). Images not to scale. Photos: Danny Haelewaters, Thomas Hiller.

Bat flies are obligate, largely host-specific, bloodsucking ectoparasites of bats [34]. They are traditionally divided into two families: the Nycteribiidae, which are most diversified in the Eastern Hemisphere, and the non-monophyletic Streblidae, which are most species-rich in the Western Hemisphere $[35,36]$. Nycteribiid bat flies are wingless, dorsoventrally flattened and have dorsally inserted legs; they vary in size from 1 to $5 \mathrm{~mm}$ [37]. Streblidae, on the other hand, are highly variable in their external morphology; they might be laterally compressed, dorsoventrally flattened, or uncompressed [38-41]. Most streblid species have functional wings. Bat flies reproduce by adenotrophic viviparity; a fertilized egg hatches inside the female fly, followed by three larval stages that are carried inside the female, nourished by an intrauterine accessory or "milk" gland. The third instar larva is deposited onto a suitable substrate in the bat roosting environment, such as a cave wall. After a developmental process of 3-4 weeks, the imago emerges in search of a bat host [39]. Diverse parasitic organisms have been reported from bat flies [42], including microscopic fungi of the ascomycete order Laboulbeniales.

Laboulbeniales are obligate biotrophic ectoparasites, producing two-celled ascospores from which a 3-dimensional thallus composed of true parenchyma develops through successive divisions in multiple planes [43]. The entire life cycle of Laboulbeniales takes place on the exoskeleton of the host, and free-living asexual stages are thus far unknown. Laboulbeniales are often host-specific [44,45]. Transmission of ascospores largely happens during host activities, such as mating and social grooming; indirect transmission is less often, due in part to the low survivability of ascospores in the environment ( $<7$ days) [46]. Laboulbeniales exhibit a large morphological and structural diversity, as well as a wide arthropod host range, which place them among the most diverse groups of parasitic fungi with 2325 described species in 145 genera [47-49]. Only four genera are found on bat flies: Arthrorhynchus, Dimeromyces, Gloeandromyces, and Nycteromyces $[33,50]$. Based on the little data available in the literature, Laboulbeniales seem to prefer female bat flies. This has been attributed to the longer life span of females, their larger size, and their fat reserves during pregnancy [51].

Here, we investigate the tripartite interaction of bats-bat flies-Laboulbeniales and measure the structural specificity of the parasites. As previously described, the parasitic organisms in this multitrophic 
association face the same threats as a result of co-endangerment as their hosts. In order to get a full picture of how this tripartite association may react to current anthropogenic changes, it is important to fully disentangle the interactions among different partners. We hope that our work can aid in developing better conservation methods, both for bats and their parasites.

\section{Materials and Methods}

Bats were captured between 1993 and 2018 in several countries in the Neotropics and Europe using mist nets or harp traps located at drinking, foraging, and swarming sites, as well as over trails that presumably functioned as flight pathways for bats. Bats were identified to species level [52-55]. Bat flies were collected using forceps, by hand, or with the help of a Fair Isle apparatus [56]. Bats were released at the vicinity of the capture site immediately after processing. Long-term storage of bat flies was in $70-96 \%$ ethanol in separate vials (one vial per bat host). Bat flies were identified using identification keys and complementary publications [57-71].

Bat flies were screened for the presence of Laboulbeniales thalli at 40-50× magnification. Thalli were removed from their host at the attachment region and slide-mounted [22,72] for identification to species level [51,72-75]. The results of this work have been incorporated into a database currently holding 11,936 bat flies with associated metadata: bat fly species and sex; bat host identification, sex, age, and reproduction status; presence/absence of Laboulbeniales, the position of infection, and fungus identification; geographic location and collecting date. Parts of this dataset have been previously published [41,51,72,76-79]. A complete list of locations where infected bat flies were collected can be found in Supplementary Table S4.

For the construction of an association web, a subset of bat flies-those infected by Laboulbeniales (Nycteribiidae: $n=45$; Streblidae: $n=287$; total $n=332$ ) -and their associated bats were used. In a few cases, the identification of the Laboulbeniales could not be determined to species level. These were all juvenile thalli of Gloeandromyces, which do not exhibit sufficient morphological features for accurate identification. These associations were grouped within "Gloeandromyces spp." In addition, some thalli of Laboulbeniales did not fit any known descriptions and thus may represent undescribed species. This was the case for thalli on three Panamanian bat flies identified as Strebla galindoi (collected from Tonatia saurophila, the Stripe-headed Round-eared Bat), listed in the association web as Gloeandromyces sp. nov. Finally, three Mexican specimens of bat fly represented an undescribed species of Trichobius (collected from Choeronycteris mexicana, the Mexican Long-Tongued Bat); they are reported in the association web as Trichobius sp. nov. Association webs were generated using the $\mathrm{R}$ language and environment for statistical computing [80], with the 'bipartite' package [81]. Species were ordered by region (Central and South America versus Europe).

Structural host specificity was described using two metrics: $H_{2}{ }^{\prime}$ and $d^{\prime}{ }_{i}$ (sensu [82]). The $H_{2}{ }^{\prime}$ index is a community-level measure of host specificity, ranging from 0 (completely generalist community) to 1 (completely specialist community). The value of the $\mathrm{H}_{2}{ }^{\prime}$ index increases as the species distribution deviates more from a null model where all species interact with other species according to their proportion of their observed frequency [82]. The $d^{\prime}{ }_{i}$ index is a metric for the specificity of each individual node-or, species-level host specificity. Like the $H_{2}{ }^{\prime}$ index, its values range from 0 (most generalist species) to 1 (most specialist species). The value of $d_{i}^{\prime}{ }_{i}$ increases as a species $i$ is observed to interact in a way that deviates from the expected distribution from a null model where all species interact in proportion to their observed numbers. These host specificity metrics were calculated using the "bipartite" package [81], with functions "H2fun" and "dfun".

In aiming to explain the presence versus absence of Laboulbeniales on certain bat flies, we hypothesized that parasitism by Laboulbeniales may be affected by bat fly ecomorphology. Streblid bat flies can be divided into three groups: wing crawlers, which feed on the membranes of the bat's wings; fur runners, which have very long posterior legs and run over the top of the fur when disturbed; and fur swimmers, which move into the fur and move through it when disturbed [41]. A subset of the bat flies in our dataset, 437 specimens collected at the Chucantí Nature Reserve, Darién Province, Panama [79], were used to 
investigate the association between ecomorphology of these bat flies and parasitism by Laboulbeniales. Statistical analysis was done using the "chisq" function in R [80].

\section{Results}

\subsection{Association Web}

The association web of the Laboulbeniales-infected bat flies can be found in Tables 1 and 2 and in Figure 2. A total of 22 bat species, 22 bat fly species, and 9 Laboulbeniales species were included. A tenth node of Laboulbeniales included Gloeandromyces spp. not identified to species level. Note that Trichobius sp. nov. (Tri_new in Figure 2) and Gloeandromyces sp. nov. (Glo_nov in Figure 2) have not been formally described in the literature. The associations of each host species with their parasite species can be found in Supplementary Tables S1 and S2. A detailed overview of all bat fly-Laboulbeniales associations thus far can be found in Supplementary Table S3.

Table 1. List of bat fly species and their associated bat hosts, numbers of collected specimens, and $d^{\prime}{ }_{i}$ values. Nycteribiid bat flies are shown in green, streblids in blue.

\begin{tabular}{|c|c|c|c|}
\hline Bat Fly Species & $\mathbf{N}$ & $d_{i}^{\prime}$ & Bat Species \\
\hline Nycteribia schmidlii & 5 & 0.47 & Miniopterus schreibersii \\
\hline Penicillidia conspicua & 38 & 0.94 & $\begin{array}{c}\text { Miniopterus schreibersii } \\
\text { Myotis daubentonii } \\
\text { Rhinolophus euryale }\end{array}$ \\
\hline Penicillidia dufouri & 2 & 1 & Myotis myotis \\
\hline Exastinion clovisi & 1 & 1 & Anoura geoffroyi \\
\hline Mastroptera guimaraesi & 13 & 0.93 & Phyllostomus hastatus \\
\hline Mastoptera minuta & 12 & 1 & Lophostoma silvicolum \\
\hline Megistopoda aranea & 4 & 1 & Artibeus jamaicensis \\
\hline Speisera ambigua & 2 & 0.12 & Carollia perspicillata \\
\hline Strebla consocia & 1 & 0.42 & Phyllostomus hastatus \\
\hline Strebla galindoi & 3 & 1 & Tonatia saurophila \\
\hline Strebla hertigi & 1 & 0.45 & Phyllostomus discolor \\
\hline Trichobioides perspicillatus & 1 & 0.45 & Phyllostomus discolor \\
\hline Trichobius costalimai & 13 & 0.95 & Phyllostomus discolor \\
\hline Trichobius dugesioides & 66 & 0.99 & Trachops cirrhosus \\
\hline Trichobius galei & 1 & 1 & Natalus stramineus \\
\hline Trichobius joblingi & 132 & 0.92 & $\begin{array}{l}\text { Carollia brevicauda } \\
\text { Carollia castanea } \\
\text { Carollia perspicillata } \\
\text { Desmodus rotundus } \\
\text { Sturnira lilium } \\
\text { Trachops cirrhosus }\end{array}$ \\
\hline Trichobius longipes & 2 & 0.54 & Phyllostomus hastatus \\
\hline Trichobius sp. nov. & 3 & 1 & Choeronycteris mexicana \\
\hline Trichobius parasiticus & 3 & 0.88 & Desmodus rotundus \\
\hline Trichobius sphaeronotus & 3 & 1 & $\begin{array}{l}\text { Leptonycteris curasoae } \\
\text { Leptonycteris nivalis }\end{array}$ \\
\hline Trichobius uniformis & 2 & 1 & Glossophaga soricina \\
\hline Trichobius yunkeri & 24 & 1 & Pteronotus parnellii \\
\hline
\end{tabular}


Table 2. List of Laboulbeniales and their association with bat fly species, numbers of collected specimens, and $d^{\prime}{ }_{i}$ values. Only Laboulbeniales identified to species level are included. Nycteribiid bat flies are shown in green, streblids in blue.

\begin{tabular}{|c|c|c|c|}
\hline Laboulbeniales Species & $\mathbf{N}$ & $d_{i}^{\prime}$ & Bat Fly Species \\
\hline Arthrorhynchus eucampsipodae & 4 & 0.94 & Nycteribia schmidlii \\
\hline Arthrorhynchus nycteribiae & 41 & 0.97 & $\begin{array}{c}\text { Nycteribia schmidlii } \\
\text { Penicillidia dufouri } \\
\text { Penicillidia conspicua }\end{array}$ \\
\hline Gloeandromyces dickii & 3 & 0.19 & Trichobius jobling $i$ \\
\hline Gloeandromyces hilleri & 12 & 1 & Mastoptera guimaraesi \\
\hline Gloeandromyces sp. nov. & 3 & 1 & Strebla galindoi \\
\hline Gloeandromyces nycteribiidarum & 10 & 0.69 & $\begin{array}{c}\text { Exastinion clovisi } \\
\text { Megistopoda aranea } \\
\text { Trichobius caecus } \\
\text { Trichobius sphaeronotus } \\
\text { Trichobius yunkeri }\end{array}$ \\
\hline Gloeandromyces pageanus & 14 & 0.21 & $\begin{array}{l}\text { Trichobius dugesioides } \\
\text { Trichobius joblingi }\end{array}$ \\
\hline Gloeandromyces streblae & 73 & 0.45 & $\begin{array}{l}\text { Megistopoda aranea } \\
\text { Trichobius dugesioides } \\
\text { Trichobius joblingi } \\
\text { Trichobius sp. nov. } \\
\text { Trichobius uniformis } \\
\text { Trichobius yunkeri }\end{array}$ \\
\hline Nycteromyces streblidinus & 23 & 0.5 & $\begin{array}{l}\text { Megistopoda aranea } \\
\text { Speisera ambigua } \\
\text { Trichobius galei } \\
\text { Trichobius joblingi } \\
\text { Trichobius longipes } \\
\text { Trichobius parasiticus }\end{array}$ \\
\hline
\end{tabular}

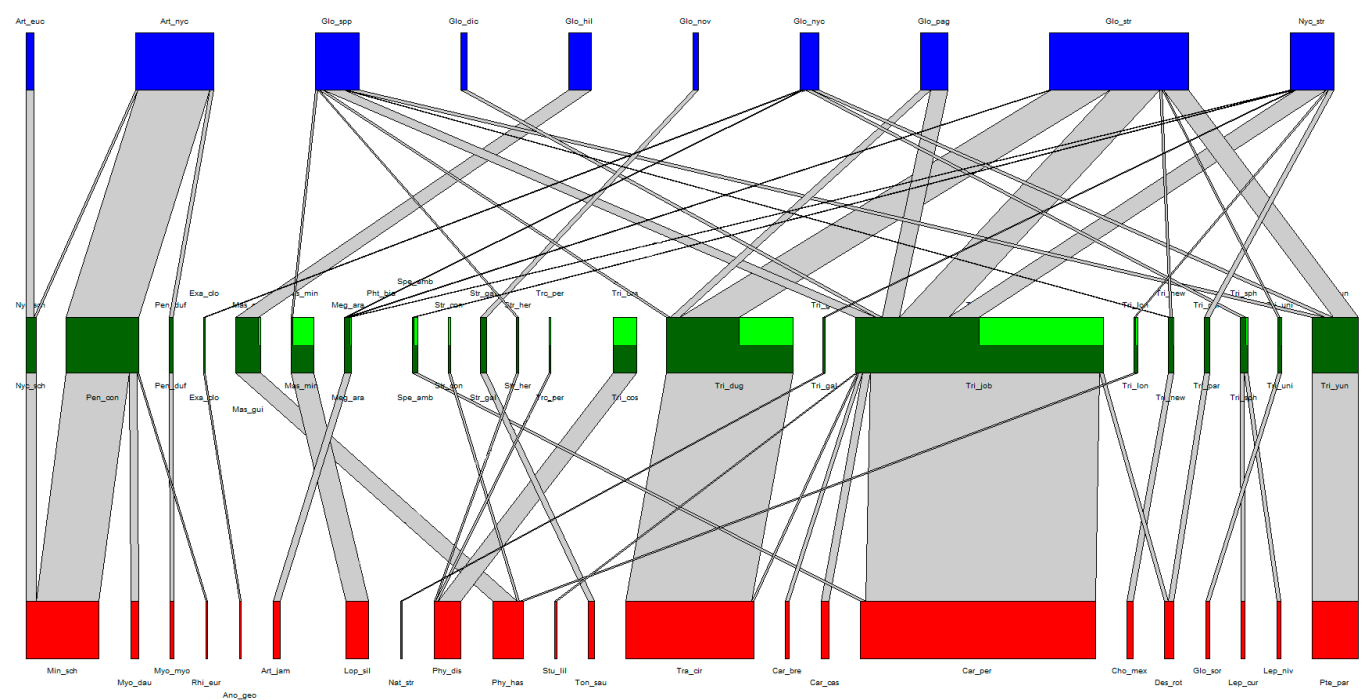

Figure 2. Quantitative bat-bat and fly-Laboulbeniales tripartite interaction network. Nodes (red, green, and blue) represent species, links (grey) represent species interactions. The width of the nodes and links corresponds to the quantitative frequency of surveyed species and the frequency of species interactions, respectively. Bat species nodes are in red, bat fly species nodes in green, and Laboulbeniales species nodes in blue. In the bat fly nodes, dark green represents those individuals of the bat fly species on which the Laboulbeniales was identified to at least genus level, whereas light green represents the individuals that were infected by Laboulbeniales but where the Laboulbeniales was not identified. 


\subsection{Structural Specificity}

We found very high host specificity at the community-level for the association of bat flies with their bat hosts $\left(H_{2}{ }^{\prime}=0.94\right)$. The community-level host specificity was also high for Laboulbeniales with their bat fly hosts $\left(\mathrm{H}_{2}{ }^{\prime}=0.65\right)$, although more generalistic compared to the bat-bat fly association. The $d^{\prime}{ }_{i}$ values of each individual species with their associated host are presented in Tables 1 and 2. Some species, such as Trichobius joblingi, were found on several host species but still have a high $d^{\prime}{ }_{i}$ value because a significant amount of specimens were found on a single host species (in the case of T. joblingi, on Carollia perspicillata).

\subsection{Ecomorphology}

Of the subset of 437 Neotropical bat flies collected at the Chucantí Nature Reserve, 69 were fur runners (of which 3 were infected by Laboulbeniales), 23 were fur swimmers ( 0 infected), and 345 were wing crawlers (27 infected). A chi-square test did not show a significant association between ecomorphology and parasitism by Laboulbeniales $\left(\chi^{2}=2.4879, p=0.2372\right)$.

\section{Discussion}

In this study, we analyzed associations among 22 bat species, 22 bat fly species, and 9 Laboulbeniales species from the Neotropics and Europe. Out of these, 15 associations between Laboulbeniales species and bat fly species had not been previously described (details in Supplementary Table S1). It is clear that the bat-bat fly-Laboulbeniales tripartite system is rich but still underexplored. Other tripartite surveys of Laboulbeniales on bat flies have been recently undertaken [79], but here we present the most up-to-date worldwide summary of bat-bat and fly-Laboulbeniales associations since Haelewaters et al. [51].

Our analysis of host specificity indicates that bat flies are very host-specific, whereas Laboulbeniales are less so. This creates a conundrum; how do ascospores of more generalist species of Laboulbeniales successfully transmit to a variety of bat fly species, when those bat flies are host-specific and stay most of their life on their bat host? Only pregnant female bat flies briefly leave their host bat to deposit a prepupa on the wall of the roosting environment, after which they need to re-colonize a new host individual for a blood meal. The pupal deposition area of Trichobius sp. is large, with the distance between observed pupae and the closest host bat roost (Natalus stramineus) ranging from 3.4 to $20.2 \mathrm{~m}$ [83]. Their depositing behavior-especially when distances are large-brings female bat flies in contact with several host bat individuals, increasing potential contacts with conspecific and heterospecific bat flies, and might be an additional reason that female bat flies have a higher frequency of Laboulbeniales infection [51]. Second, ascospores of Laboulbeniales are usually transmitted directly through interactions among arthropod hosts such as grooming and mating activities $[46,49]$. Because bats are more likely to be infested, more likely to carry heavier parasite loads, and more likely to harbor more species of bat fly in more permanent roosting structures (caves and tunnels, as opposed to leaf tents) [27], Laboulbeniales might have more opportunities to disperse to new host species in these roosts where many different bat fly species gather.

Another avenue of study could be to investigate the factors that determine why Laboulbeniales fungi are associated with different hosts. Are there any similarities in morphology or behavior among the bat fly hosts of a single species of Laboulbeniales, or do the bat hosts of those bat flies associated with a Laboulbeniales parasite species have a similar life history? Bat flies prefer specific body regions to settle on their host bats, and these preferences are associated with differences in bat fly morphology and behavior [38,41]. Our analysis of ecomorphology of bat flies versus Laboulbeniales infection as a whole saw no significant differences in infection prevalence for one or the other ecomorphological group. However, on a species-level, ascospores of Laboulbeniales might adhere easier to and develop better on bat fly body parts that are associated with specific bat fly ecomorphology - e.g., on the elongated posterior legs of fur runners. Laboulbeniales infections in other host groups such as beetles (Hexapoda: Coleoptera), corixids (Hexapoda: Hemiptera), and pill-millipedes (Diplopoda: Sphaerotheriida) can be position-specific, and some even 
exhibit sex-of-host specificity [49]. This makes it not unimaginable that bat fly ecomorphotype and the associated microhabitat on the bat host may affect the prevalence of Laboulbeniales infection as well, although the exact mechanics of these associations are as yet unstudied.

A few caveats must be considered. First, the geographic range of bats and their associates included in this study was limited to Costa Rica, Honduras, Mexico, Panama, Peru, and Trinidad (Neotropics), and Hungary and Romania (Europe). In future analyses, we should include data from more localities, including in African and Asian countries. Second, a few associations were represented by only a single specimen -in these cases, the single connection between parasite and host makes the parasite species highly "host-specific" while not necessarily being so. The use of $d^{\prime}{ }_{i}$ values for host specificity of species is a standard analysis tool and has been used to show specificity in, e.g., ticks and their hosts [16], bees and the plants they frequent [84], and scavengers and the carcasses they choose [85]. However, in our study, the interpretability of $d_{i}^{\prime}$ values may be more limited, as $d^{\prime}{ }_{i}$ is dependent on host abundance; due to scarcity of the host and the parasite, even a parasite that only occurs on a single host species can get a value lower than 1 . In a system of highly specialized parasites with low abundances such as the bat-bat fly-Laboulbeniales system, $d^{\prime}{ }_{i}$ values become distorted. More specimens would make the species-level host specificity measures more robust. Third, it should be noted that distributions of parasites among hosts might not only be determined by the availability of hosts; they are also influenced by abiotic factors such as temperature and humidity $[78,86]$.

Parasites affect the topology and stability of food webs, and they influence ecosystem health $[87,88]$. The effects of Laboulbeniales on their hosts have not been well-studied. Laboratory bioassays have only been performed for one species; Hesperomyces virescens increases the mortality of native and invasive ladybirds [89]. But how do Laboulbeniales associated with bat flies affect their hosts? Resolving this question as well as if and how biotic and abiotic traits may affect the tritrophic interactions among bats, bat flies, and Laboulbeniales fungi, will continue to decipher the long-neglected bat-hyperparasitic system. Here, we studied and discussed associations and host specificity. All in all, parasites are a crucial factor that can shape food webs and species distribution patterns, but they are notoriously understudied. Recently, a global parasite conservation plan was put forward, proposing, among others, more concentrated efforts to describe their current distribution so that existing predictions can be validated and improved about how parasites and their hosts are affected by a changing world [3,5]. Studies such as this one aid ecologists, parasitologists, and conservation biologists to work towards a better global understanding of parasitism, and add to an increasing body of literature showing that we should not underestimate this omnipresent mode of life.

Supplementary Materials: The following are available online at http://www.mdpi.com/2309-608X/6/4/361/s1, Table S1: List of bat species and their associations with bat fly species. Nycteribiid bat flies are shown in green, streblids in blue. The IUCN Red List status for each bat species [29] has been added within parentheses: LC = least concern, $\mathrm{NT}=$ near threatened, VU = vulnerable, EN = endangered. Table S2: List of bat fly species and their associations with Laboulbeniales. Nycteribiid bat flies are shown in green, streblids in blue. Table S3: Summary of all known Laboulbeniales associated with bat flies so far. Adapted from Haelewaters et al. [51] and updated with data from Szentiványi et al. [77,90], Walker et al. [79], Dogonniuck et al. [50], Haelewaters and Pfister [75], Liu et al. [72] (marked in red), and the database used for this paper (marked in blue). Table S4: List of localities of the infected bat fly specimens used, with coordinates.

Author Contributions: Conceptualization, M.D.d.G. and D.H.; methodology, T.H., A.D.S., T.S., and D.H.; formal analysis, M.D.d.G.; data curation, M.D.d.G. and D.H.; writing-original draft preparation, M.D.d.G., I.D., and D.H.; writing-review and editing, M.D.d.G., I.D., T.H., A.D.S., T.S., M.S., M.C.A., A.V., and D.H.; visualization, M.D.d.G. and D.H.; supervision, M.S., A.V., and D.H.; project administration, M.D.d.G. and D.H.; funding acquisition, T.H., A.D.S., M.C.A., and D.H. All authors have read and agreed to the published version of the manuscript.

Funding: Data used in this paper could only be generated after extensive fieldwork, supported by the following sources: to T.H.: German Research Foundation (DFG) (SPP 1596 Grant TS 81/6-1) and Smithsonian Tropical Research Institute (Research Fellowship); to A.D.S.: ÚNKP 19-4-ÁTE-10 New National Excellence Programme of the MIT and National Research, Development and Innovation Office (Hungary) 132794; to D.H.: Harvard University Herbaria (Fernald Fund), David Rockefeller Center for Latin American Studies (Summer Research Travel Grant), Smithsonian Tropical Research Institute (Short-Term Research Fellowship), and Mycological Society of America (Graduate Fellowship, Robert W. Lichtwardt Student Research Award). This work was supported in part by a 
USDA National Institute of Food and Agriculture Hatch project (1010662 to M.C.A.) and a Junior Postdoctoral Fellowship from the Research Foundation-Flanders (1206620N to D.H.).

Acknowledgments: We are most grateful to Carl W. Dick (Western Kentucky University) and Rachel A. Page (Smithsonian Tropical Research Institute) for sharing data. We also acknowledge valuable input from two anonymous reviewers.

Conflicts of Interest: The authors declare no conflict of interest.

\section{References}

1. Bowler, D.E.; Bjorkman, A.D.; Dornelas, M.; Myers-Smith, I.H.; Navarro, L.M.; Niamir, A.; Supp, S.R.; Waldock, C.; Vellend, M.; Blowes, S.A.; et al. Mapping human pressures across the planet uncovers anthropogenic threat complexes. People Nat. 2020, 2, 380-394. [CrossRef]

2. Marcogliese, D.J. Parasites of the superorganism: Are they indicators of ecosystem health? Int. J. Parasitol. 2005, 35, 705-716. [CrossRef]

3. Carlson, C.J.; Hopkins, S.; Bell, K.C.; Doña, J.; Godfrey, S.S.; Kwak, M.L.; Lafferty, K.D.; Moir, M.L.; Speer, K.A.; Strona, G.; et al. A global parasite conservation plan. Biol. Conserv. 2020, 250, 108596. [CrossRef]

4. Windsor, D.A. Most of the species on Earth are parasites. Int. J. Parasitol. 1998, 28, 1939-1941. [CrossRef]

5. Carlson, C.J.; Burgio, K.R.; Dougherty, E.R.; Phillips, A.J.; Bueno, V.M.; Clements, C.F.; Castaldo, G.; Dallas, T.A.; Cizauskas, C.A.; Cumming, G.S.; et al. Parasite biodiversity faces extinction and redistribution in a changing climate. Sci. Adv. 2017, 3, e1602422. [CrossRef] [PubMed]

6. Poulin, R.; Morand, S. The diversity of parasites. Q. Rev. Biol. 2000, 75, 277-293. [CrossRef] [PubMed]

7. Poulin, R.; Randhawa, H.S. Evolution of parasitism along convergent lines: From ecology to genomics. Parasitology 2015, 142, S6-S15. [CrossRef] [PubMed]

8. de Baets, K.; Littlewood, D.T.J. The importance of fossils in understanding the evolution of parasites and their vectors. Adv. Parasitol. 2015, 90, 1-51. [CrossRef]

9. Lafferty, K.D.; Allesina, S.; Arim, M.; Briggs, C.J.; de Leo, G.; Dobson, A.P.; Dunne, J.A.; Johnson, P.T.J.; Kuris, A.M.; Marcogliese, D.J.; et al. Parasites in food webs: The ultimate missing links. Ecol. Lett. 2008, 11, 533-546. [CrossRef]

10. Sato, T.; Egusa, T.; Fukushima, K.; Oda, T.; Ohte, N.; Tokuchi, N.; Watanabe, K.; Kanaiwa, M.; Murakami, I.; Lafferty, K.D. Nematomorph parasites indirectly alter the food web and ecosystem function of streams through behavioural manipulation of their cricket hosts. Ecol. Lett. 2012, 15, 786-793. [CrossRef]

11. Brearley, G.; Rhodes, J.; Bradley, A.; Baxter, G.; Seabrook, L.; Lunney, D.; Liu, Y.; Mcalpine, C. Wildlife disease prevalence in human-modified landscapes. Biol. Rev. 2013, 88, 427-442. [CrossRef] [PubMed]

12. Colwell, R.K.; Dunn, R.R.; Harris, N.C. Coextinction and persistence of dependent species in a changing world. Ann. Rev. Ecol. Evol. Syst. 2012, 43, 183-203. [CrossRef]

13. Dunn, R.R.; Harris, N.C.; Colwell, R.K.; Koh, L.P.; Sodhi, N.S. The sixth mass coextinction: Are most endangered species parasites and mutualists? Proc. R. Soc. B 2009, 276, 3037-3045. [CrossRef] [PubMed]

14. Strona, G. Past, present and future of host-parasite co-extinctions. Int. J. Parasitol Parasites Wildl. 2015, 4, 431-441. [CrossRef]

15. Poulin, R.; Krasnov, B.R.; Morand, S. Patterns of host specificity in parasites exploiting small mammals. In Micromammals and Macroparasites—from Evolutionary Ecology to Management; Morand, S., Krasnov, B.R., Poulin, R., Eds.; Springer: Tokyo, Japan, 2006; pp. 233-256.

16. Esser, H.J.; Herre, E.A.; Blüthgen, N.; Loaiza, J.R.; Bermúdez, S.E.; Jansen, P.A. Host specificity in a diverse Neotropical tick community: An assessment using quantitative network analysis and host phylogeny. Parasites Vectors 2016, 9, 372. [CrossRef]

17. Holt, R.D.; Dobson, A.P.; Begon, M.; Bowers, R.G.; Schauber, E.M. Parasite establishment in host communities. Ecol. Lett. 2003, 6, 837-842. [CrossRef]

18. Koh, L.P.; Dunn, R.R.; Sodhi, N.S.; Colwell, R.K.; Proctor, H.C.; Smith, V.S. Species coextinctions and the biodiversity crisis. Science 2004, 305, 1632-1634. [CrossRef]

19. Poulin, R.; Krasnov, B.R.; Mouillot, D. Host specificity in phylogenetic and geographic space. Trends Parasitol. 2011, 27, 355-361. [CrossRef]

20. Parratt, S.R.; Laine, A.-L. The role of hyperparasitism in microbial pathogen ecology and evolution. ISME J. 2016, 10, 1815-1822. [CrossRef] 
21. Parratt, S.R.; Barrès, B.; Penczykowski, R.M.; Laine, A.L. Local adaptation at higher trophic levels: Contrasting hyperparasite-pathogen infection dynamics in the field and laboratory. Mol. Ecol. 2017, 26, 1964-1979. [CrossRef]

22. Haelewaters, D.; Page, R.A.; Pfister, D.H. Laboulbeniales hyperparasites (Fungi, Ascomycota) of bat flies: Independent origins and host associations. Ecol. Evol. 2018, 8, 8396-8418. [CrossRef] [PubMed]

23. Gleason, F.H.; Lilje, O.; Marano, A.V.; Sime-Ngando, T.; Sullivan, B.K.; Kirchmair, M.; Neuhauser, S. Ecological functions of zoosporic hyperparasites. Front. Microbiol. 2014, 5, 244. [CrossRef] [PubMed]

24. Holt, R.D.; Hochberg, M.E. The coexistence of competing parasites. Part II - Hyperparasitism and food chain dynamics. J. Theor. Biol. 1998, 193, 485-495. [CrossRef] [PubMed]

25. Simmons, N.B.; Cirranello, A.L. Bat Species of the World: A taxonomic and geographic database. Available online: https://batnames.org (accessed on 6 November 2020).

26. Patterson, B.D.; Dick, C.W.; Dittmar, K. Roosting habits of bats affect their parasitism by bat flies (Diptera: Streblidae). J. Trop. Ecol. 2007, 23, 177-189. [CrossRef]

27. Gannon, M.R.; Bovard, B.N. The value of bats: Keystone species in the Keystone State. In Conservation and Ecology of Pennsylvania's Bats; Butchkoski, C.M., Reeder, D.M., Turner, G.G., Whidden, H.P., Eds.; The Pennsylvania Academy of Science: Allentown, PA, USA, 2016; pp. 5-31.

28. Maine, J.J.; Boyles, J.G. Bats initiate vital agroecological interactions in corn. Proc. Natl. Acad. Sci. USA 2015, 112, 12438-12443. [CrossRef]

29. International Union for Conservation of Nature. The IUCN Red List of Threatened Species. Version 2020-2. Available online: https://www.iucnredlist.org (accessed on 28 October 2020).

30. Frick, W.F.; Kingston, T.; Flanders, J. A review of the major threats and challenges to global bat conservation. Ann. N. Y. Acad. Sci. 2019, 5-25. [CrossRef]

31. Naegle, M.A.; Mugleston, J.D.; Bybee, S.M.; Whiting, M.F. Reassessing the phylogenetic position of the epizoic earwigs (Insecta: Dermaptera). Mol. Phylogenet. Evol. 2016, 100, 382-390. [CrossRef]

32. Reeves, W.K.; Beck, J.; Orlova, M.V.; Daly, J.L.; Pippin, K.; Revan, F.; Loftis, A.D. Ecology of bats, their ectoparasites, and associated pathogens on Saint Kitts Island. J. Med. Entomol. 2016, 53, 1218-1225. [CrossRef]

33. Haelewaters, D.; Hiller, T.; Dick, C.W. Bats, bat flies, and fungi: A case of hyperparasitism. Trends Parasitol. 2018, 34, 784-799. [CrossRef]

34. Dick, C.W.; Patterson, B.D. Against all odds: Explaining high host specificity in dispersal-prone parasites. Int. J. Parasitol. 2007, 37, 871-876. [CrossRef]

35. Dittmar, K.; Porter, M.L.; Murray, S.; Whiting, M.F. Molecular phylogenetic analysis of nycteribiid and streblid bat flies (Diptera: Brachycera, Calyptratae): Implications for host associations and phylogeographic origins. Mol. Phylogenet. Evol. 2006, 38, 155-170. [CrossRef] [PubMed]

36. Dittmar, K.; Morse, S.F.; Dick, C.W.; Patterson, B.D. Bat fly evolution from the Eocene to the present (Hippoboscoidea, Streblidae and Nycteribiidae). In Parasite Diversity and Diversification-Evolutionary Ecology Meets Phylogenetics; Morand, S., Krasnov, B.R., Timothy, D., Littlewood, J., Eds.; Cambridge University Press: Cambridge, UK, 2015; pp. 246-264.

37. Dick, C.W.; Pospischil, R. Nycteribiidae (bat flies). In Encyclopedia of Parasitology; Mehlhorn, H., Ed.; Springer: Berlin, Germany, 2015. [CrossRef]

38. Dick, C.W. Ecology and Host Specificity of Neotropical Bat Flies (Diptera: Streblidae) and Their Chiropteran Hosts. Ph.D. Thesis, Texas Tech University, Lubbock, TX, USA, 2005.

39. Dick, C.W.; Patterson, B.D. Bat flies: Obligate ectoparasites of bats. In Micromammals and Macroparasites: From Evolutionary Ecology to Management; Morand, S., Krasnov, B., Poulin, R., Eds.; Springer: Tokyo, Japan, 2006; pp. 179-194.

40. Dick, C.W.; Miller, J.A. Streblidae. In Manual of Central American Diptera; Brown, B.V., Borkent, A., Cumming, J.M., Wood, D.M., Woodley, N.E., Zumbado, M., Eds.; National Research Council Press: Ottawa, ON, Canada, 2010; Volume II, pp. 1249-1260.

41. Hiller, T.; Honner, B.; Page, R.A.; Tschapka, M. Leg structure explains host site preference in bat flies (Diptera: Streblidae) parasitizing neotropical bats (Chiroptera: Phyllostomidae). Parasitology 2018, 145, 1475-1482. [CrossRef] [PubMed]

42. Szentiványi, T.; Christe, P.; Glaizot, O. Bat flies and their microparasites: Current knowledge and distribution. Front. Vet. Sci. 2019, 6, 115. [CrossRef] [PubMed] 
43. Blackwell, M.; Haelewaters, D.; Pfister, D.H. Laboulbeniomycetes: Evolution, natural history, and Thaxter's final word. Mycologia 2020, 112, in press. [CrossRef]

44. De Kesel, A. Host specificity and habitat preference of Laboulbenia slackensis. Mycologia 1996, 88, 565-573. [CrossRef]

45. Haelewaters, D.; De Kesel, A.; Pfister, D.H. Integrative taxonomy reveals hidden species within a common fungal parasite of ladybirds. Sci. Rep. 2018, 8, 15966. [CrossRef]

46. De Kesel, A. Relative importance of direct and indirect infection in the transmission of Laboulbenia slackensis (Ascomycetes, Laboulbeniales). Belg. J. Bot. 1995, 128, 124-130.

47. Roskov, Y.; Ower, G.; Orrell, T.; Nicolson, D.; Bailly, N.; Kirk, P.M.; Bourgoin, T.; DeWalt, R.E.; Decock, W.; van Nieukerken, E.; et al. Species 2000 \& ITIS Catalogue of Life, 2019 Annual Checklist. Available online: https://www.catalogueoflife.org/annual-checklist/2019 (accessed on 15 November 2020).

48. Haelewaters, D.; Dima, B.; Abdel-Hafiz, B.I.I.; Abdel-Wahab, M.A.; Abul-Ezz, S.R.; Acar, I.; Aguirre-Acosta, E.; Aime, M.C.; Aldemir, S.; Ali, M.; et al. Fungal Systematics and Evolution 6. Sydowia 2020, 72, 231-356. [CrossRef]

49. Haelewaters, D.; Blackwell, M.; Pfister, D.H. Laboulbeniomycetes: Intimate fungal associates of arthropods. Ann. Rev. Entomol. 2021, 66, 13.1-13.20. [CrossRef]

50. Dogonniuck, A.E.; Squires, T.J.; Weir, A. Studies on Dimorphomyceteae: I. New species of Nycteromyces and Dimeromyces (Laboulbeniales) on bat flies (Streblidae). Mycologia 2019, 111, 118-126. [CrossRef]

51. Haelewaters, D.; Pfliegler, W.P.; Szentiványi, T.; Földvári, M.; Sándor, A.D.; Barti, L.; Camacho, J.J.; Gort, G.; Estók, P.; Hiller, T.; et al. Parasites of parasites of bats: Laboulbeniales (Fungi: Ascomycota) on bat flies (Diptera: Nycteribiidae) in Central Europe. Parasites Vectors 2017, 10, 96. [CrossRef] [PubMed]

52. Handley, C.O., Jr. Checklist of the mammals of Panama. In Ectoparasites of Panama; Wenzel, R.L., Tipton, V.J., Eds.; Field Museum of Natural History: Chicago, IL, USA, 1966; pp. 753-795.

53. Timm, R.M.; LaVal, R.K. A field key to the bats of Costa Rica. In Occasional Publication Series; University of Kansas Center of Latin American Studies: Lawrence, KS, USA, 1998; Volume 22, pp. 1-30.

54. Dietz, C.; Kiefer, A. Bats of Britain and Europe; Bloomsbury Publishing: London, UK, 2016.

55. Murariu, D.; Chişamera, G.; Măntoiu, D.Ş.; Pocora, I. Romanian Fauna. Mammalia. Volume XVI, Fascicle 3: Chiroptera; Editura Academiei Române: Bucharest, Romania, 2016.

56. Williamson, K. The Fair Isle apparatus for collecting bird ectoparasites. Brit. Birds 1954, 47, 235-236.

57. Theodor, O.; Moscona, A. On bat parasites in Palestine. I. Nycteribiidae, Streblidae, Hemiptera, Siphonaptera. Parasitology 1954, 44, 157-245. [CrossRef] [PubMed]

58. Wenzel, R.L.; Tipton, V.J. Ectoparasites of Panama; Field Museum of Natural History: Chicago, IL, USA, 1966.

59. Theodor, O. An Illustrated Catalogue of the Rothschild Collection of Nycteribiidae in the British Museum (Natural History), with Keys and Short Descriptions for the Identification of Subfamilies, Genera, Species and Subspecies; British Museum (Natural History) Publication: London, UK, 1967.

60. Wenzel, R.L. The streblid batflies of Venezuela (Diptera: Streblidae). Brigh. Young Univ. Sci. Bull. 1976, 20, 1-177. [CrossRef]

61. Guerrero, R. Catalogo de los Streblidae (Diptera: Pupipara) parasitos de murcielagos (Mammalia: Chiroptera) del Nuevo Mundo I. Clave para los géneros y Nycterophiliinae. Acta Biol. Venez. 1993, 14, 61-75.

62. Guerrero, R. Catalogo de los Streblidae (Diptera: Pupipara) parasitos de murcielagos (Mammalia: Chiroptera) del Nuevo Mundo II. Los grupos: Pallidus, caecus, major, uniformis y longipes del género Trichobius (Gervais, 1844). Acta Biol. Venez. 1994, 15, 1-18.

63. Guerrero, R. Catalogo de los Streblidae (Diptera: Pupipara) parasitos de murcielagos (Mammalia: Chiroptera) del Nuevo Mundo IV. Trichobiinae con alas desarrolladas. Bol. Entomol. Venez. 1994, 9, 161-192.

64. Guerrero, R. Catalogo de los Streblidae (Diptera: Pupipara) parasitos de murcielagos (Mammalia: Chiroptera) del Nuevo Mundo III. Los grupos: Dugesii, dunni y phyllostomae del género Trichobius (Gervais, 1844). Acta Biol. Venez. 1995, 15, 1-27.

65. Guerrero, R. Catalogo de los Streblidae (Diptera: Pupipara) parasitos de murcielagos (Mammalia: Chiroptera) del Nuevo Mundo V. Trichobiinae con alas reducidas o ausentes y miscelaneos. Bol. Entomol. Venez. 1995, 10, 135-160.

66. Guerrero, R. Catálogo de los Streblidae (Diptera: Pupipara) parásitos de murciélagos (Mammalia: Chiroptera) del Nuevo Mundo VI. Streblinae. Acta Biol. Venez. 1996, 16, 1-26. 
67. Guerrero, R. Catálogo de los Streblidae (Diptera: Pupipara) parásitos de murciélagos (Mammalia: Chiroptera) del Nuevo Mundo VII. Lista de especies, hospedadores y países. Acta Biol. Venez. 1997, 17, 9-24.

68. Guerrero, R. Notes on Neotropical batflies (Diptera, Streblidae). I. The genus Trichobius, with description of two new species and one new subspecies from Venezuela. Acta Parasitol. 1998, 43, 86-93.

69. Guerrero, R. Notes on Neotropical bat flies (Diptera: Streblidae): II. Review of the genus Xenotrichobius. Acta Parasitol. 1998, 43, 142-147.

70. Miller, J.; Tschapka, M. The Bat Flies of La Selva (Diptera: Nycteribiidae, Streblidae). Available online: http://www.biologie.uni-ulm.de/bio3/Batfly/index.html (accessed on 14 November 2020).

71. Dick, C.W. Review of the bat flies of Honduras, Central America (Diptera: Streblidae). J. Parasitol. Res. 2013, 437696. [CrossRef]

72. Liu, J.; Haelewaters, D.; Pfliegler, W.P.; Page, R.A.; Dick, C.W.; Aime, M.C. A new species of Gloeandromyces from Ecuador and Panama revealed by morphology and phylogenetic reconstruction, with a discussion of secondary barcodes in Laboulbeniomycetes taxonomy. Mycologia 2020, 112, in press. [CrossRef]

73. Thaxter, R. Contribution toward a monograph of the Laboulbeniaceae. Part II. Mem. Am. Acad. Arts Sci. 1908, 13, 217-469. [CrossRef]

74. Thaxter, R. Contribution towards a monograph of the Laboulbeniaceae. Part III. Mem. Am. Acad. Arts Sci. 1924, 14, 309-426.

75. Haelewaters, D.; Pfister, D.H. Morphological species of Gloeandromyces (Ascomycota, Laboulbeniales) evaluated using single-locus species delimitation methods. Fungal Syst. Evol. 2019, 3, 19-33. [CrossRef]

76. Estrada-Villegas, S.; Halczok, T.K.; Tschapka, M.; Page, R.A.; Brändel, S.D.; Hiller, T. Bats and their bat flies: Community composition and host specificity on a Pacific island archipelago. Acta Chiropt. 2018, 20, 161-176. [CrossRef]

77. Szentiványi, T.; Haelewaters, D.; Pfliegler, W.P.; Clément, L.; Christe, P.; Glaizot, O. Laboulbeniales (Fungi: Ascomycota) infection of bat flies (Diptera: Nycteribiidae) from Miniopterus schreibersii across Europe. Parasites Vectors 2018, 11, 395. [CrossRef]

78. Szentiványi, T.; Haelewaters, D.; Rádai, Z.; Mizsei, E.; Pfliegler, W.P.; Báthori, F.; Tartally, A.; Christe, P.; Glaizot, O. Climatic effects on the distribution of ant- and bat fly-associated fungal ectoparasites (Ascomycota, Laboulbeniales). Fungal Ecol. 2019, 39, 371-379. [CrossRef]

79. Walker, M.J.; Dorrestein, A.; Camacho, J.J.; Meckler, L.A.; Silas, K.A.; Hiller, T.; Haelewaters, D. A tripartite survey of hyperparasitic fungi associated with ectoparasitic flies on bats (Mammalia: Chiroptera) in a neotropical cloud forest in Panama. Parasite 2018, 25, 19. [CrossRef] [PubMed]

80. RStudio Team. RStudio: Integrated Development for R. Available online: https://www.rstudio.com/ (accessed on 16 November 2020).

81. Dormann, C.F.; Gruber, B.; Fründ, J. Introducing the bipartite package: Analysing ecological networks. $R$ News 2008, 8, 8-11.

82. Blüthgen, N.; Menzel, F.; Blüthgen, N. Measuring specialization in species interaction networks. BMC Ecol. 2006, 6, 9. [CrossRef]

83. Dittmar, K.; Dick, C.W.; Patterson, B.D.; Whiting, M.F.; Gruwell, M.E. Pupal deposition and ecology of bat flies (Diptera: Streblidae): Trichobius sp. (caecus group) in a Mexican cave habitat. J. Parasitol. 2009, 95, 308-314. [CrossRef]

84. Fründ, J.; Dormann, C.F.; Holzschuh, A.; Tscharntke, T. Bee diversity effects on pollination depend on functional complementarity and niche shifts. Ecology 2013, 94, 2042-2054. [CrossRef]

85. Moleón, M.; Sánchez-Zapata, J.A.; Sebastián-González, E.; Owen-Smith, N. Carcass size shapes the structure and functioning of an African scavenging assemblage. Oikos 2015, 124, 1391-1403. [CrossRef]

86. Cumming, G.S. Host distributions do not limit the species ranges of most African ticks (Acari: Ixodida). Bull. Entomol. Res. 1999, 89, 303-327. [CrossRef]

87. Cumming, G.S.; van Vuuren, D.P. Will climate change affect ectoparasite species ranges? Glob. Ecol. Biogeogr. 2006, 15, 486-497. [CrossRef]

88. Pilosof, S.; Dick, C.W.; Korine, C.; Patterson, B.D.; Krasnov, B.R. Effects of Anthropogenic disturbance and climate on patterns of bat fly parasitism. PLoS ONE 2012, 7, e41487. [CrossRef] 
89. Haelewaters, D.; Hiller, T.; Kemp, E.A.; van Wielink, P.S.; Shapiro-Ilan, D.I.; Aime, M.C.; Nedvěd, O.; Pfister, D.H.; Cottrell, T.E. Mortality of native and invasive ladybirds co-infected by ectoparasitic and entomopathogenic fungi. PeerJ 2020, 8, e10110. [CrossRef] [PubMed]

90. Szentiványi, T.; Kravchenko, K.; Vlaschenko, A.; Estók, P. First record of Laboulbeniales (Fungi: Ascomycota) infection on bat flies (Diptera: Nycteribiidae) from the Caucasus region. Folia Entomol. Hung. 2018, 79, 195-201. [CrossRef]

Publisher's Note: MDPI stays neutral with regard to jurisdictional claims in published maps and institutional affiliations.

(C) 2020 by the authors. Licensee MDPI, Basel, Switzerland. This article is an open access article distributed under the terms and conditions of the Creative Commons Attribution (CC BY) license (http://creativecommons.org/licenses/by/4.0/). 